\title{
An Evaluation of Sea Level Rise Vulnerability and Resilience Strategy to Climate Change in the Coastline of Bangladesh
}

Asirul Haque ${ }^{1}$, Md. Habibur Rahman ${ }^{2,3 *}$ and Dilara Rahman ${ }^{4}$

${ }^{1}$ Department of Political Science, Government MC College, Bangladesh

${ }^{2}$ Graduate School of Agriculture, Kyoto University, Japan

${ }^{3}$ Bangladesh Institute of Social Research (BISR) Trust, Bangladesh

${ }^{4}$ Department of Political Studies, Shaahjalal University of Science and Technology, Bangladesh

Submission: February 25, 2019; Published: March 29, 2019

*Corresponding author: Md. Habibur Rahman, Graduate School of Agriculture, Kyoto University, Japan

\begin{abstract}
Bangladesh — a low-lying South Asian country— is highly susceptible to the adverse impact of global climate change particularly to sea level rise (SLR) due to its unique geographical settings and poor socio-economic condition of the vulnerable people. Scientific projections showed that projected SLR ranged from $0.53-0.97 \mathrm{~m}$ in 37 coastal stations for the year of 2100 , where the predicted global SLR is $0.09-0.88 \mathrm{~m}$. World Bank assessed that 1.5 to 1.54 million people would be affected by 2070 by one-meter SLR and permanent relocation of 13 million people. Therefore, the review study investigated the potential impacts of SLR in Bangladesh along with the adaptation strategies i.e., community-based adaptation (CBA), indigenous knowledge (IK)-based adaptation and structural adaptation to enhance the resilience building capacity in the coastal zone of Bangladesh. The country has developed and implemented numerous successful CBA projects to mitigate vulnerabilities from SLR, flooding, water logging and salinity. This study argues that community participation makes a significant impact on reducing SLR vulnerabilities and enhancing community resilience capacity, and community involvement in decision-making process is very crucial for a successful resilience building process. IK assists the community in making informed decisions about how to respond to SLR changes and about how to adapt and improve the situation. The structural adaptations include the rehabilitation of coastal embankment, construction of multipurpose cyclone shelters, and coastal afforestation. Finally, to ensure pro-poor climate governance and effective adaptation and resilience to SLR, the government should respect local communities and institutions who work for them, heed their adaptation priorities, and change the top-down approaches to bottom-up approaches.
\end{abstract}

Keywords: Community participation; Indigenous knowledge; Community-based adaptation; Structural adaptation; Mainstreaming adaptation; Coastal zone management; Sea level rise

Abbrevations: AR: Assessment Report; AR5: Fifth Assessment Report; BCCSAP: Bangladesh Climate Change Strategy and Action Plan; CBA: Community-Based Adaptation; CBACC-CF: Community-Based Adaptation to Climate Change through Coastal Afforestation; CBO: CommunityBased Organization; CCHPU: Climate Change and Health Promotion Unit; CIDA: Canadian International Development Agency; CSO: Civil Society Organization; CZP: Coastal Zone Policy; FAO: Food and Agriculture Organization of the United Nations; GMSL: Global Mean Sea Level; IK: Indigenous Knowledge; IPCC: Intergovernmental Panel on Climate Change; IUCN: International Union for Conservation of Nature; LACC: Livelihood Adaptation to Climate Change; LDRRF: Local Disaster Risk Reduction Fund; NAPA: National Adaptation Programme of Action; NGO: Non-Governmental Organization; SAR: Second Assessment Report; SLR: Sea Level Rise; TAR: Third Assessment Report

\section{Introduction}

Climate change and the associated rise in global mean temperature is projected to lead to accelerating global mean sea level rise (SLR) over the twenty-first century. Two major causes of SLR were identified. First one is the expansion of ocean water due to global warming induced thermal expansion, and the second is the addition of ice water on the ocean from the land through the melting of glacier ice sheets [1]. The combined impact of these two causes has increased global sea level by at least $0.6 \mathrm{~m}$ by the end of the century (for the period 2090-2099 relative to 1980-1999) [2]. Studies indicate that ice sheets from the Greenland and Antarctica could contribute an additional $0.3 \mathrm{~m}$ SLR by the end of the century
$[2,3]$. The U.S. Global Change Research Program projected that by the year 2100 , the average SLR would have been between $0.3 \mathrm{~m}$ and $1.2 \mathrm{~m}$ since the 2014 assessment [4]. The Intergovernmental Panel on Climate Change (IPCC) argued that the consequences of SLR will likely be greater for least developed countries and small island countries.

The Fifth Assessment Report (AR5) of the IPCC reported that, recent observations of global average SLR at a rate of $0.0032 \mathrm{~m}$ per year and projected that if greenhouse gas emissions continue to keep up with the current rate, global average sea level could rise by nearly one-meter by 2100 [1]. World Bank [5] explains that 
SLR is happening more rapidly than it was projected earlier. It is almost unavoidable to see a $0.5 \mathrm{~m}$ rise in sea level by 2050 due to past greenhouse gas emissions. If the world community particularly developed and industrialized countries could limit warming to $2^{\circ} \mathrm{C}$, it may limit SLR to $0.7 \mathrm{~m}$ by the end of this century. On the other hand, if greenhouse gas emission increases and global temperature rises to $4^{\circ} \mathrm{C}$ by 2100 , sea level projected to be rise one $\mathrm{m}$ and $1.10-1.15 \mathrm{~m}$ near to the equator. However, most of the SLR related impact studies have focused only on the developed countries and provide limited data on developing and coastal countries [2].

An increasing trend in the global mean sea level (GMSL) has been observed under different climate change scenarios reported by the five IPCC reports (Figure1). The First Assessment Report (FAR) estimated an average GMSL rise of $1.2 \pm 0.3 \mathrm{~mm} /$ year for the period of 1880-1982. The Second Assessment Report (SAR) estimated an average GMSL rise of $1.8 \pm 0.8 \mathrm{~mm} /$ year over the $20^{\text {th }}$ century. This range is slightly higher than the FAR estimates. The Third Assessment Report (TAR) estimated an average GMSL rise of $1.8 \pm 0.1 \mathrm{~mm} /$ year for the $20^{\text {th }}$ century. The value is almost like SAR estimates but with reduced uncertainty. The Fourth Assessment Report (AR4) estimated an average GMSL rise of $1.8 \pm 0.5 \mathrm{~mm} /$ year for the period of 1961-2003. The AR5 estimated observed SLR rates based on geological data and instrumental record (tide gauge and satellite data). Records of tide gauge stations suggest that the long-term trend in GMSL rise is $1.7 \pm 0.2 \mathrm{~mm} /$ year between 1901 and 2010. From the high-precision satellite altimetry record of 1993-2012, a GMSL rate of $3.2 \pm 0.4 \mathrm{~mm} /$ year and from 19932003, a GMSL rate of $3.1 \pm 0.7 \mathrm{~mm} /$ year have been observed.

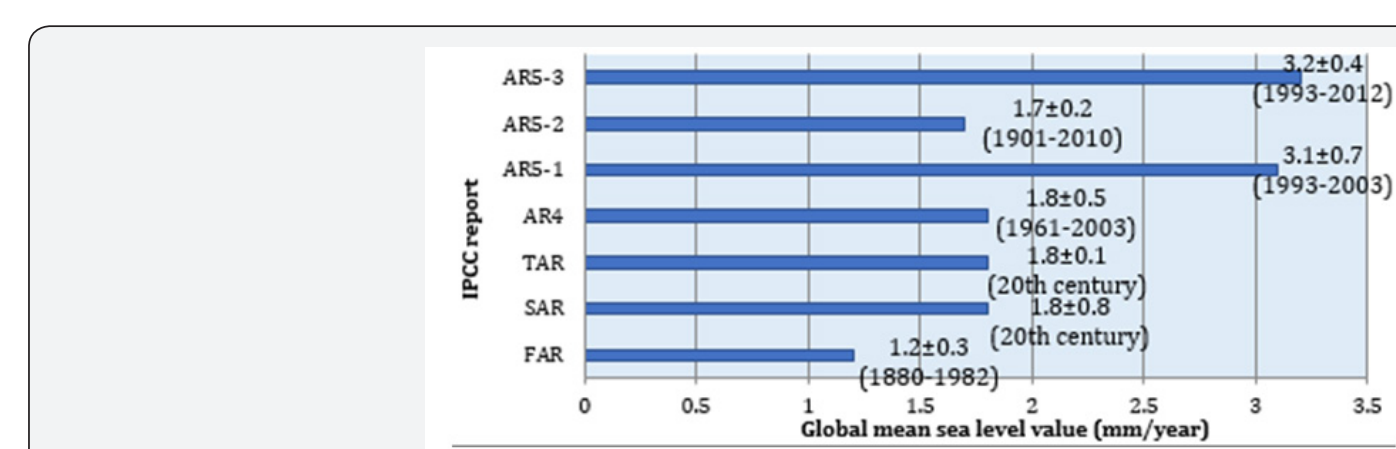

Figure 1: Comparative value of observed global mean sea level (source: compiled from the IPCC assessment reports). Note: AR: Assessment Report; SAR: Second Assessment Report; TAR: Third Assessment Report.

Table 1: The risk from sea level rise between $2010-2100$ in South Asia.

\begin{tabular}{|c|c|c|c|c|}
\hline SLR/Temperature & Around $1.5^{\circ} \mathrm{C}(2030)$ & Around $2^{\circ} \mathrm{C}(2040)$ & Around $3^{\circ} \mathrm{C}(2060)$ & Around $4^{\circ} \mathrm{C}(2080)$ \\
\hline \multirow{3}{*}{$0.2 \mathrm{~m}$ in 2010} & $0.3 \mathrm{~m}$ in 2040 & $0.3 \mathrm{~m}$ in 2040 & $0.3 \mathrm{~m}$ in 2040 & $0.3 \mathrm{~m}$ in 2040 \\
\hline & $0.5 \mathrm{~m}$ in 2070 & $0.5 \mathrm{~m}$ in 2070 & $0.5 \mathrm{~m}$ in 2060 & $0.5 \mathrm{~m}$ in 2060 \\
\hline & $0.7 \mathrm{~m}$ in $2080-2100$ & $0.7 \mathrm{~m}$ in $2080-2100$ & $0.9 \mathrm{~m}$ in $2080-2100$ & $1.05 \mathrm{~m}$ in $2080-2100$ \\
\hline
\end{tabular}

South Asia is more vulnerable to climate change as at $4^{\circ} \mathrm{C}$ global warming sea level is projected to be rise approximately $0.9-1.05 \mathrm{~m}$ by $2080-2100$, monsoon rainfall to become more variable with greater frequency of devastating floods, as well as prolonged droughts. Glacier melting and snow cover loss could be severe, and unusual heat extremes in the summer months (June to August) are projected to affect $70 \%$ of the land area (Table 1).

The coastalzones of the world contain large human populations and significant socio-economic activities. Fertile coastal lowlands, abundant marine resources, water transportation, aesthetic beauty, and intrinsic values have long motivated coastal population. Coastal economies include commercial, recreational, and subsistence fisheries; ports and industrial facilities that rely on shipping; and tourism, agriculture, and forestry dependent on the coastal climate [6]. Based on the recent projections, it was observed that current and future climate change would be expected to have several impacts, particularly on coastal socialecological systems. The impacts are flooding, SLR, erosion, salinity, cyclone and storm surge, changes in surface water quality and groundwater characteristics, impacts on agriculture and aquaculture, coastal infrastructures which have direct impact on community in different forms like displacement of people, loss of livelihoods, and submergence of low-lying areas as well as the socio-economic costs [2,7].

Bangladesh, a low-lying country facing the Bay of Bengal, comprises of 19 coastal districts (among 12 districts are exposed to the sea and lower estuaries) consisting of $710 \mathrm{~km}$ which make the country one of the most disaster-prone and climatevulnerable countries in the world $[8,9]$. The coastal area lies about 1.5-11.8m above the mean sea level. The estuarine islands are constantly being changed shape and position due to river erosion and new alluvial deposition. These areas are subject to flooding in the monsoon season and waterlogging in parts of the basin areas in the dry season [10]. Scholars have analysed risks of SLR in Bangladesh from different perspectives like human security risk [11,12], adaptation, and mitigation [13], the involvement of local institutions (non-governmental organizations (NGOs), civil society organizations (CSOs) and community-based organizations 
(CBOs)) $[14,15]$, however, only a very few discussed the issue of SLR vulnerabilities and resilience strategies in the coastline of Bangladesh.

Bangladesh is on the forefront for adaptation efforts among least developed countries, which has gained experience with 'community-based adaptation (CBA)' approaches and could potentially serve as a role model for other countries. A CBA approach can be very effective in resilience building process as the climate change vulnerability takes place mainly at the local level where people encounter impacts, build adaptive capacity, and response [16]. The concept is considered most suitable to implement adaptation on the community level, according to actual needs and capabilities, to empower people to help themselves, and develop local ownership for adaptation, and avoid mal-adaptation To fight against imminent SLR related risks several CBA initiatives have been undertaken by the donors, government, development partners, and local institutions along the coastal zones of Bangladesh. However, due to the lack of proper government initiatives and follow-up and highly centralized organizational setup, climate change adaptation and resilience projects failed to show their actual outputs [17]. Therefore, it is worth to investigate what are the impacts of SLR in the coastline of Bangladesh, how communities can adapt with the vulnerability and changes, what are the initiatives of government and local institutions, the role of indigenous knowledge and structural adaptation can contribute to resilience building process of the local vulnerable communities. This review study reviewed and analysed SLR related reports and project documents of government agencies, donors, NGOs, CSOs and CBOs, as well as scholarly articles on SLR, CBA, indigenous knowledge (IK)-based adaptation, structural adaptation and community resilience to climate change and SLR related issues in Bangladesh. Photographs of examples on SLR related adaptations (CBA, IK-based adaptation and structural adaptation) in Bangladesh also collected from internet searching with given proper citation.

\section{Sea level rise and its impacts on the coastline of Ban- gladesh}

The AR5 indicates that vast coastal communities living in the South Asian countries such as Bangladesh are becoming increasingly vulnerable to the imposing threat of SLR. Bangladesh located in the delta of three large river systems in the world - the Ganges, the Brahmaputra and Meghna. This unique geographical setting makes the country highly vulnerable to SLR as the coastal zone covering the country's $32 \%$ of the total land mass where $28 \%$ of the total population (density 1,000/ $\mathrm{km}^{2}$ ) living here [18]. More than half of the coastal zone (56.37\%) in Bangladesh are currently threatened with cyclonic storm surges with around $45 \%$ area under threat from surges of more than one-meter [19]. Drainage congestion and water logging are already an alarming problem and likely to be exacerbated by SLR and increased river flooding. As a result of reduced upstream flow, the silt flocculates/deposit in the riverbed which restricts the removal of excess water from the countryside and causes drainage congestion [20].

Salinity intrusion in the coastal regions is one of the major effects of SLR, which is currently evident in not only the various existent freshwater sources but also in the soil, thus threatening drinking water security and crop production. The intrusion of saline water will continue as the area under one-ppt salinity line is expected to increase by $18.22 \%$ and area under 5ppt salinity is expected to increase $24 \%$ by 2050 [21]. Due to increased SLR, already $53 \%$ of the coastal areas have been affected by salinity. This leads to decrease the agricultural productivity; increased food insecurity, along with increased salinity in drinking water sources by affecting groundwater. However, salinity limits the opportunity for supplemental irrigation of Aus. rice cultivation (sown in March-April, benefits from monsoon rains, and is harvested during July-August) in freshwater areas and damages the same crops by flooding during very high tides [22,23].

Based on global sea level data and modelling, Ericson et al. [24] have estimated that the SLR of the Bay of Bengal is the world's highest, at 10mm/year. A 22 years tidal gauge data (1977-1998) found that the tidal level in Hiron Point, Char Changa and Cox's Bazar coastal stations rose by 4.0,6.0 and $7.8 \mathrm{~mm} /$ year respectively [25]. In addition, the ground water level is sinking slightly because of tectonic movements that pushed up the average relative SLR [26]. Another study observed SLR at different tidal water level stations in Hiron Point, Moheshkhali, Sandwip and Cox's Bazar and found the change in mean SLR was 5.5, 7.5, 5.05 and 7.04mm/ year respectively from the period of 1968-2002 [21]. United Kingdom's Department for Environment, Food and Rural Affairs [27] calculated that the projected SLR ranged from $0.53-0.97 \mathrm{~m}$ in 37 coastal stations on the southern coast of Bangladesh for the year of 2100, where the predicted global SLR is $0.09-0.88 \mathrm{~m}$ for 2100. Finally, the Climate Change Cell of Bangladesh considered that the range of SLR on Bangladesh coast over the 30 years is 6-21mm/year [20].

Furthermore, a World Bank [5] study also identified the following potential threats of SLR in the coastline of Bangladesh:

a) some 1.5-1.54 million people would be affected by 2070 by one-meter SLR and permanent relocation of 13 million people;

b) about 20 million people are already affecting by salinity intrusion in their drinking water;

c) contamination of drinking water by salinity intrusion may cause increasing diseases;

d) extreme heat and more intense cyclone threatening food production and security, livelihoods and infrastructures, and slow down the poverty alleviation strategies;

e) about $40 \%$ of the agricultural land will be lost by $0.0065 \mathrm{~m}$ SLR in 2040;

f) by 2040 , a $0.27 \mathrm{~m}$ SLR with storm surges could inundate an 
area of more than $80 \%$ larger than the area inundated at present by a similar event.

Brecht et al. [28] reported that 1.5 million people in Dhaka, Chittagong and Khulna cities would be affected by one-meter SLR by 2070. Hanson et al. [29] estimated that only 0.5m SLR could be exposed to nearly 17 million people in Bangladesh. On the other hand, Yu et al. [30] calculated that rice production in Bangladesh will reduce approximately 80 million ton from 2005-2050 (loss of US $\$ 2.68$ billion per year) which decline the $5.14 \%$ of national gross domestic product due to SLR and other climatic impacts.

An anthropogenic $0.45 \mathrm{~m}$ SLR combined with other forms of anthropogenic stress on the Sundarbans the world's largest natural mangrove forest could lead to the destruction of $75 \%$ of the Sundarbans mangroves [31]. This would not only affect coastal ecosystems but also thousands of poor households depending on the Sundarbans resources. It is evident that mangroves can mitigate or reduce the risk of natural disasters such as cyclones and tsunamis [32-34]. Furthermore, a meter SLR may cause complete losses of the Sundarbans resulting loss of heritage, biodiversity and fisheries resources. A $0.28 \mathrm{~m}$ SLR will cause a decline of $96 \%$ iconic Royal Bengal Tigers (Panthera tigris tigris) habitat [35]. In addition, the distribution and habitat of the important cetaceans (aquatic mammals including such as dolphins) in Sundarbans, the Ganges river dolphin- (Platanista gangetica) preferring also to be affected due to SLR [36].

SLR along with high winds would allow saline water to overtop the existing coastal protection embankments and submerge polders, which will affect crop yields and livelihood security. Salt water from the Bay of Bengal is reported to have penetrated $100 \mathrm{~km}$ or more along tributary channels during the dry season in past years. Approximately 1.02 million ha of arable lands have been affected to varying degrees by soil salinity, and vast areas of croplands in the lower estuary of the coast remain fallow during the dry (or rabi, winter cropping season) season due to high salinity [37].

\section{Adaptation and resilience strategy to sea level rise in Bangladesh}

\section{Community-based adaptation approach}

CBA to climate change identifies long-term adaptation knowledge, transformed resilience, and adaptive capacity of vulnerable communities. CBA recognizes that environmental knowledge, vulnerability, and resilience to climatic impacts are embedded in societies and cultures. This means the focus is on empowering communities to act based on their own decision-making processes. Increased resilience to climate stresses can be achieved by enabling communities to enhance their capacity to cope with climate extreme. Ideally, CBA is a community-led and driven process - a partnership between institutions and communitiesrather than something done for and imposed upon local peoples [38]. Although CBA is an emerging area, efforts are being made to develop participatory methodologies, raise awareness on climate change and foster adaptive capacity.

CBA is a community-led process, based on communities' priorities, needs, knowledge, and capacities, which should empower people to plan for and cope with the impacts of climate change [39]. In the light of increasing evidence that climate change is exerting on the lives and livelihoods of the poorest people in climate-vulnerable regions, and disappointment at the 'top-down' nature of much adaptation planning and investment that is failing to reach the most vulnerable, CBA projects and programmes are increasing in number and reach. However, despite this increase in attention to and practice of CBA, there remains a lack of participatory, practical, replicable and relevant methodologies for measuring, monitoring and evaluating the results of adaptation in general, and CBA in particular [40].

Although community-based interventions are necessarily situated at the local level, it is crucial to recognise that CBA also demands and promotes action at all other levels to achieve systemic and long-term change. CBA framework of CARE (a humanitarian organization) provides a holistic analytical approach for communities to plan adaptation actions that are informed by climate science as well as by local observations of climate change. It builds the capacities of local and government institutions to better support communities' adaptation efforts. It also addresses underlying causes of vulnerability, such as poor governance, gender-based inequality over resource use, or access to basic services, by influencing the policy and enabling environment. The 'CBA 'flower' diagram" (Figure 2) to emphasise the use of climate information, and the uncertain nature of climate risk, in guiding project/community decision-making as the critical distinguishing features of adaptation work [41].

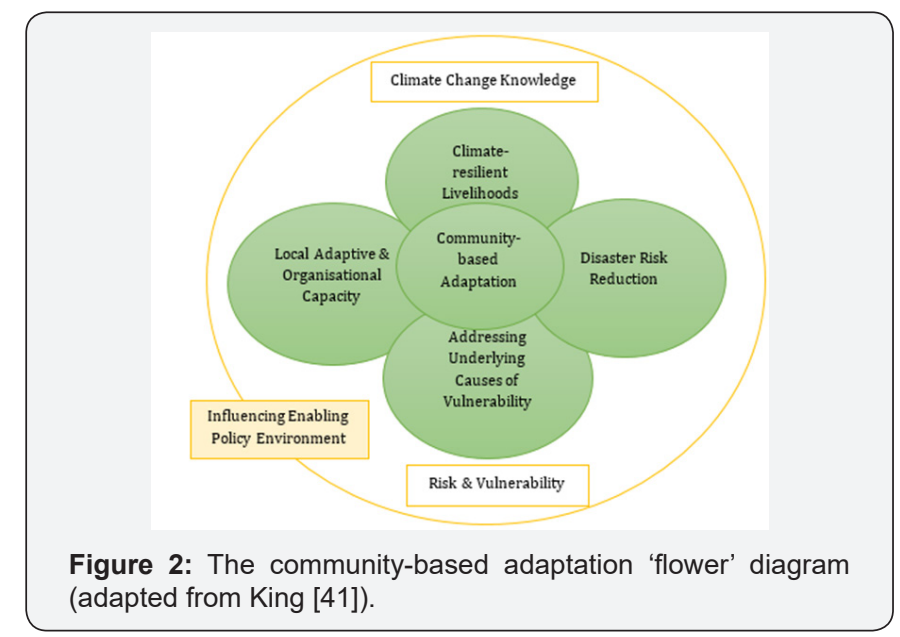

CBA has been recognized and promoted by the donor agencies in Bangladesh as a valid approach to coping with the adverse impact of climate change. The development collaborates like Asian Development Bank (ADB), Japan International Cooperation Agency (JICA), United States Agency for International Development (USAID), Canadian International Development Agency (CIDA), Department for International Development (DFID), Food and Ag- 
riculture Organization of the United Nations (FAO), Swiss Agency for Development and Cooperation (SDC), Swedish International Development Cooperation Agency (SIDA), United Nations Development Programme (UNDP) and World Bank are actively taking part in CBA to climate change in coastal Bangladesh. Different international agencies supported from development partners like International Union for Conservation of Nature (IUCN), CARE, Practical Action, ActionAid, WaterAid, Islamic Relief Worldwide, Save the Children, Plan International, Oxfam, Concern Worldwide, Caritas, Christian Aid, World Fish, Bangladesh Centre for Advanced Studies (BCAS), and Action Research for Community Adaptation in Bangladesh (ARCAB) providing technical and financial support to local level NGOs for implementing CBA projects in vulnerable areas to address the imminent threat of SLR. All the CBA projects support the livelihood of a very high proportion of the country's climate vulnerable population.

UNDP in Bangladesh emphasizes that the country needs to focus on CBA approach for water and agriculture sector to reduce the climate induced risks (i.e. SLR, salinity, flooding and water logging) and to protect its biodiversity and ecosystem [42]. With the growing emphasis on CBA approach, many national and international NGOs are working in Bangladesh to make the local people accustomed to newer adaptive options and the technologies compatible to geographical, ecological and unique lifestyle [43]. Scholars argued that local people have the skills, experience, local knowledge and networks to take effective resilience strategy to fight against adverse situation including climate change risks [44]. CBA, therefore, could be very effective for Bangladesh, since almost one-third (31.5\%) of its population is living below the extreme poverty line [45].

CBA initiatives in coastal Bangladesh can reach and benefit every single SLR affected community but need to be strategic at several levels. At the household level, it might be better to invest in ducks rather than chickens if flooding is becoming increasingly problematic. At the community level, it might make sense to cut losses and relocate a community if sea levels are rising and problems relating to seawater inundation are increasing, rather than investing in strengthening physical barriers to keep the sea at bay. While floating and hanging vegetable gardens have proved useful in coastal Bangladesh in the context of helping communities cope with the ever-increasing problems of water logging [46], hanging or floating roads or medical centres are not feasible [47].

'The Local Disaster Risk Reduction Fund (LDRRF)' in Bangladesh is an example for the successful upscaling CBA project in the coastal areas. The LDRRF's key objective was to support the implementation of risk reduction measures identified by vulnerable communities through community risk assessment. LDRRF provides grants to NGOs and local governments, who implement risk reduction measures at the community level under the leadership of local Disaster Management Committees. The project has provided funds for 699 small-scale risk reduction interventions across five districts and will eventually reach 40 vulnerable dis- tricts to climate change [48].

Using radio and school curricula to communicate risks and empower communities with knowledge of risk preparedness, is another successful example of how expanding partnerships to work with other sectors, can enhance the reach of messages and information to communities, and scale-up CBA to protect health. The Climate Change and Health Promotion Unit (CCHPU) under the Ministry of Health and Family Welfare has been piloting several health adaptation projects to translate national risk management priorities to the community level. Mechanisms they have been using include:

a) Community-based research on the sensitivity of health to climatic conditions [49];

b) Community radio and 'edutainment' to communicate risks and transmit education about preparedness;

c) Empowerment of youth as local activists, risk communicators and health advocates;

d) Mainstreaming climate change risk awareness into school curricula to sensitise children to hazards and protective health behaviour; and

e) CBA using public-private partnership (PPP) at vulnerable locations [50].

CCHPU in the coastal districts developed a school manual, 'Climate Change and Health Safety', to create awareness of climate risks to health among parents, students, and teachers. The manual was based on two World Health Organization manuals for students and teachers (WHO- SEARO 2008) [51]. A range of stakeholders specialised in disease control and education, from government and civil society, came together with experts in climate change and education manual development in order to incorporate the manual into the National School Curriculum. The CCHPU and two local NGOs of two different coastal areas at Kaliganj, Shatkhira (Radio Nolta) and Shitakundu, Chittagong (Radio Sagorgiri) have jointly developed two-hour-long radio programmes broadcast daily. These radio shows are an 'edutainment' approach, using folk media and local languages to reach vulnerable communities on increasing community awareness of health risks associated with climate change, the preventive actions they could take to stay healthy and how to understand and respond to various alerts issued by early warning systems for imminent threats of local floods and cyclones [50].

In the flood-prone haor (wetland) area of Bangladesh, vulnerable people are now using floating garden (a floating garden is built using aquatic weeds mostly by water hyacinth with soil and compost as a base on which vegetables can be grown) technology or locally known as baira during the flood and water logging (Figure 3), and found useful for improving nutritional security, income, employment, and land use capacity [52]. The size of the raft can be made to suit the circumstances of the user. Leafy vege- 
tables, ladies' finger, gourd, bean, eggplant, radish, potato, pumpkin, and spices including chili, onion, garlic, turmeric and mustard crops can produce and can move from one place to another. After the end of the growing season, the rafts are used as compost [53]. During periods of flood and water logging, field crops often perish, but crops on baira can survive. It was found that the lo- cal practice was improved with scientific and technological input by NGOs. This resulted in longer and stronger beds, cultivation of diversified vegetables and crops rotation, as well as people can meet their household food requirements and earn an additional income [54].

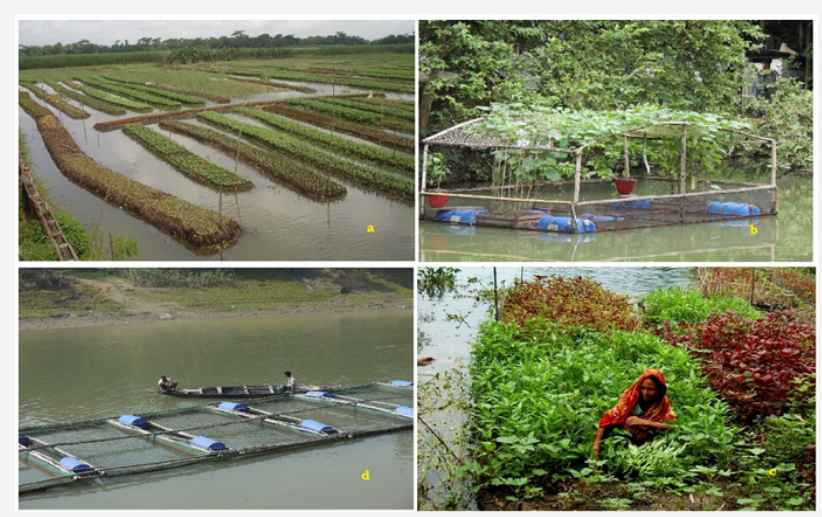

Figure 3: Floating garden agriculture in Bangladesh:

a) Floating seedbeds in the submerged agri-field with newly seedlings (source: Wetland Resource Development Society);

b) Integrated floating cage-aquaponics system (source: flickr/theworldfishcenter);

c) A woman harvesting vegetables form her floating garden (source: www.saltwaterin.blogspot.com);

d) Freshwater cage aquaculture (source: www.inclusivebusiness.net)

Cage aquaculture (Figure 3), another promising CBA strategy in Bangladesh to assist poor villager in developing small-scale cage culture practices to produce a range of freshwater fish species which could provide food for home consumption and earn income. The choice of species included Tilapia (Oreochromis niloticus), Chinese carps (Cyprinus carpio), catfish (Pangassius spp.), silver carp (Oreochromis niloticus), crab (Scylla serata) and the freshwater prawn. Cage culture has advantages over other aquaculture systems that are potentially important in terms of uptake by rural poor and landless people. This technique would be more promising during flood and water logging condition [17].

Likewise, in Noakhali, a coastal district of Bangladesh, raising and reinforcing homestead to cope with the flooding and cyclone is another example of a successful CBA which was implemented by IUCN. The project builds an IK-based building design which includes raising foundations of house structure and raising platforms within homes where people can take shelter during flood or cyclone and reduce need to flee from their homes [55]. CIDA initiated a project called 'Reducing Vulnerability to Climate Change' for six coastal districts in Bangladesh which were implemented by CARE-Bangladesh. The goal of the project was to increase adaptive capacity and awareness of local communities to address the adverse impact of climate change, especially of SLR. The findings of the project were: improved the community understanding and responding capacity to climate change; local organizations were better able to manage the climate change impacts and acquired skills and knowledge to advocacy; local government organizations were sensitized to the need for strategic interventions to enhance the adaptive capacity of the communities [56].

In addition, to address the salinity problem in Sundarbans mangrove forest, villagers building their houses on a raised platform and reserved rainwater in sealed containers, called Motki made by potter and buried into clay soil near houses. Similarly, they started shrimp farming as an alternative to rice cultivation [57]. Additionally, another study systematically explored the importance of IK to climate change, CBA approach to adaptation and sustainable people's development in the coastal areas of Bangladesh [58]. Furthermore, Rawlani and Sovacool [59] examine the drivers, benefits, and challenges to CBA in Bangladesh. They explored how the 'Community-Based Adaptation to Climate Change through Coastal Afforestation (CBACC-CF)' project builds various types of adaptive capacity in coastal areas and its implementation and what lessons offer it for other adaptation programmes. The study summarized that the technology by itself is only a partial element of successful adaptation efforts where cross-sectoral, institutional, and infrastructural dimensions are needed, to build effective resilience process.

'Integrated Planning for Sustainable Water Management' was another good example for successful project implementation where local communities were directly involved in the project planning and implementation. Bangladesh Water Development Board initiated the project in the southwestern coastal region with the assistance of the Dutch Government to manage water re- 
sources and related issues with meaningful local people's participation. The project ensured water management organizations of local communities with effective participating in planning and supervision of construction which created a kind of sense of ownership of the scheme among them [60]. All over, CBA projects in Bangladesh shows that the rate of acceptance of adaptation strategies was very high where local communities were directly involved in projects implementation.

Practical Action implemented the 'Strengthening Community Resilience in the Southwestern Coastal Area' project after devastating cyclone Aila (2009) to improve the resilience of coastal communities through strengthened ecosystem functions and protected livelihoods. The communities are now benefitting from improved aquaculture practices and reduced negative pressure on natural aquatic animals, thereby enhancing livelihood opportunities.

Center for Natural Resource Studies (CNRS) — a national NGO of Bangladesh - implemented the 'Piloting Climate-Resilient Development Initiatives (2011-2012)' project in a riverine area in order to improve CBA capacity by piloting sustainable agriculture practices and promoting land conservation. Demonstration and promotion of saline-tolerant rice varieties, promotion of crab $(S$. serata) fattening and duck breeding, alternative crops, and crop intensification were improved agriculture production whilst reducing the effect of climate-related risks. Additionally, the project increased the capacity for coping with natural weather hazards by rehabilitating, reforestation mangrove forests, and renovating house and boat structures.

Gram Bikash Shohayak Shangstha (GBSS) - a local NGO of Bangladesh - implemented the 'Coping with Climate Risks by Empowering Women in Coastal Areas' project to reduce the vul- nerability of people living in Dashmina Upazila by establishing 'Women Resource Centers' that fostered a community approach to climate change awareness and adaptation planning. Teams of 1820 women were responsible for establishing and operating seed banks, planting nurseries, building vegetable gardens, rearing livestock, and coordinating climate change awareness campaigns. By empowering marginalized women, this project increased their access to resources, diversified livelihood activities, health and sanitation needs, and agricultural production.

'Community-based Adaptation in Vulnerable Coastal Areas of Bangladesh (2011-2013)' another successful CBA project implemented by Practical Action in order to mainstream climate change adaptation and disaster risk reduction in community-level planning and programming. The project improved community understanding and capacity on climate change and variability and improved preparedness measure, enhanced adaptive and risk reduction capacity of the vulnerable community with viable adaptation options (agriculture, aquaculture, low-cost service for safe drinking water, climate-resilient community shelter/homes, solar home systems, biogas plants and clean technology such as plantation, improved kitchen, etc.).

Satkhira Unnayan Sangstha (SUS) - a local NGO of Bangladesh - has been implemented several CBA initiatives in the coastal areas such as reed (Cyperus tagetiformus) cultivation, promoting local (indigenous) rice varieties and time management to cope with flood and drought, dyke cropping to cope with water logging and salinity, agriculture on raised mound and homestead gardening, commercially production of salt tolerant grass, crab (S. serata) cultivation, rainwater storage for drinking, and demonstrate and promote flood-resistant houses, etc. The Figure 4 shows different types of CBA to sea level rise in the coastline of Bangladesh such as:

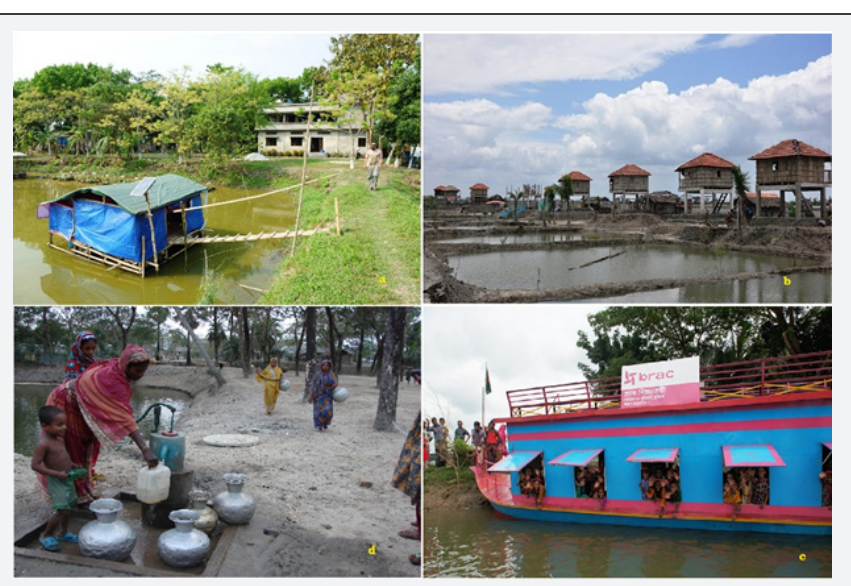

Figure 4: Different types of community-based adaptation to sea level rise in the coastline of Bangladesh:

a) Floating house concept is experimenting in the field (source: http.climateadapted.blogspot.com);

b) Raised house for the coastal people to protect from flooding and water logging (source: www.climatechangenews.com);

c) Boat school for children (source: educateachild.org);

d) Artificial aquifer tubewell to treat contaminated surface water for domestic use on the saline-prone area (source: practicalaction.org). 
a) Floating house concept is experimenting in the field;

b) Raised house for the coastal people to protect from flooding and water logging;

c) Boat school for children;

d) Artificial aquifer tubewell to treat contaminated surface water.

Social networks - bonding networks with family and relatives, and bridging networks with neighbours and friends- another form of CBA and play a significant role during and after disasters in the coastal areas. Studies argued that rural people depend on their social network and knowledge sharing which has an important role to accept adaptation strategies and enhance community participation in decision-making [61-63]. Lack of awareness about risks related to SLR and choosing associated adaptive options make coastal dwellers dependent on their social networks about what to do for coping with climate change vulnerabilities, for example, shifting to saline tolerant crops, taking shelter during the storm surge and choosing livelihood options. Moreover, it was found that women act as a powerful agent in the social network. Other social actors like government and non-governmental agencies focus more on the needs of women for short-term and long-term support [9]. Other studies observed that lack of social network and capital tend to have less capacity to cope with disasters, increased traumatic stress disorder like depression and other psychosocial symptoms of the affected people [64,65]. Most resilient communities are work together toward a common goal where social networks allow individuals to draw on community resources and increase the likelihood that such communities can effectively address their collective concerns [66].

\section{Indigenous knowledge-based approach}

Rural IK-based approaches play an important role to reduce climate change vulnerability from early warning to take action against climatic impacts as an immediate coping strategy, hence contributing to climate change adaptation. A few studies on local and IK-based adaptation to climate change have been pursued in Bangladesh, such as [67-72]. These studies have found that such knowledge is practised from generation to generation and assists the community in making informed decisions about how to respond to environmental changes and about how to adapt and improve the situation. Although the local knowledge is time-, placeand culture-specific it makes individual and community adaptive as well as increases resilience capacity towards climate variability and change.

Some other studies have identified remedies and practices of communities for overcoming the challenges of SLR-related variability and change. These include floating garden in water-logged conditions [73,74], construction of floating platform for cattle refuge during floods [73], building earthen embankments supported by bamboo fences and grass planting to reduce flood erosion [75], implementing water drainage systems around homesteads to stop salinity intrusion in the soil [76], and shifting cultivation time to avoid floods [73]. The knowledge associated with native rice varieties also indicates their potential to tolerate drought, salinity, tidal submergence and waterlogging expected under climate change regimes [77].

Practices of IK facilitate the reduction of project cost and increasing production cost. For example, Bass and Ramasamy [78] referring a CBA project called 'Livelihood Adaptation to Climate Change (LACC)' initiated by FAO to promote livelihood adaptation and reduce vulnerability to climate change in drought-prone and coastal regions of Bangladesh. Their study observed that the adoption of rainwater harvesting and supplemental irrigation during drought improved the rice yield by $23 \%$ and net profit by $75 \%$. Water saving irrigation practice increased the water use efficiency of rice by $20 \%$ but yield and economic advantage are marginal due to the low cost of water. Adoption of the improved stove at household level requires an investment of US\$10/household, while it saves 30\% fuel use and reduces 35\% time for cooking.

Alam [70] evaluates how IK and preparatory activities reduce the impact of climate change hazards and natural disaster of coastal dwellers of Bangladesh. The study also argued that people could anticipate storm surge from a 'sense of cold' without noticing weather signal. These anticipations prompt them to take shelter in safer places before storm surge occurs and reduces casualty likely to emanate from the devastating storm surges. The study concluded that people's approach is more viable than the migration of the disaster-impacted people. Another innovative IKbased adaptation in the southwestern coastal region of Bangladesh is 'Tidal River Management'. This is a unique IK-based river management by the local community through collective efforts, where a huge area of land being raised to solve the severe drainage congestion and water logging problem caused by deposition of sediments in the main rivers $[79,80]$.

Integrated farming of crops, fish and livestock in the same field plays an important role in increasing food production and more income in the saline, waterlogged and drought-prone areas of Bangladesh. The system is better than monoculture in terms of resource utilization, diversity, productivity, and both the quality and quantity of the food produced [81]. Using the Cobb-Douglas production function model, Ahmed [82] shown that the highest average annual productivity of rice per hectare was found in integrated farming $(10,178 \mathrm{~kg})$ followed by rice monoculture $(9,691 \mathrm{~kg})$ and alternate farming $(4,986 \mathrm{~kg})$. Moreover, in the submerged land area, spanning partly or a whole year, duck rearing can be a good CBA to use water logging productively.

In addition, CBA in agriculture can build on a large pool of existing IK and scientific knowledge. FAO experience (project reports 2008-2011) suggests that the value of local and traditional agricultural practices is essential to shape long-term adaptation. FAO projects have led to successful results when replicating indigenous and known local practices in areas where they were not 
practised before, and by complementing them with other practices based on scientific knowledge. This included, for instance, the integrated testing of indigenous and research-based salt and submerge-tolerant rice varieties in Bangladesh [83]. FAO [84] also recognised the importance of cultural awareness raising programme (such as posters, leaflets, videos, folk and drama) on climate change adaptation in agriculture implemented by the 'LACC' project in Bangladesh. The Figure 5 shows different types of IK- based adaptation approaches in the coastline of Bangladesh as for example:

a) Villagers rebuild an embankment;

b) Women are preparing a climate change vulnerability map;

c) Swimming learning training for the children; and

d) Climate change awareness through "Pot song' (Bangla folk music).

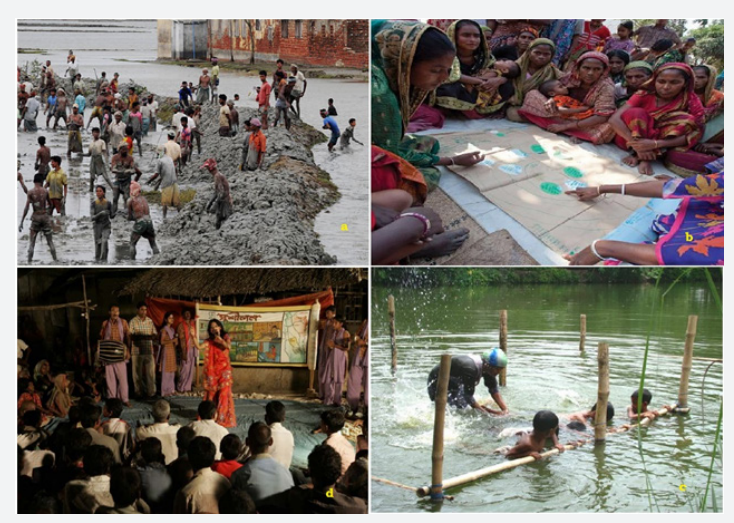

Figure 5: Different types of indigenous knowledge-based adaptation approaches in the coastline of Bangladesh:

a) Villagers rebuild an embankment (source: www.gettyimages.co.uk);

b) Women are preparing a climate change vulnerability map (source: www.care.org);

c) Swimming learning training for the children (source: www.jessicamudditt.com);

d) Climate change awareness through 'Pot song' (source: www.machizo.com).

\section{Structural adaptation}

Rehabilitation of coastal embankment: The major adaptation measures against flooding in the coastal region of Bangladesh are the construction of earthen embankments along the rivers as well as parallel to the coastline. The embankments are designed primarily to prevent flooding during high astronomical tides and are found useful during cyclone-generated storm surge too. These embankments are mostly useful to agricultural productions and flood protection. Due to recent SLR trends, the government has increased the heights and strengthening by planting trees along its sloping faces under social forestry regime (Figure 6).

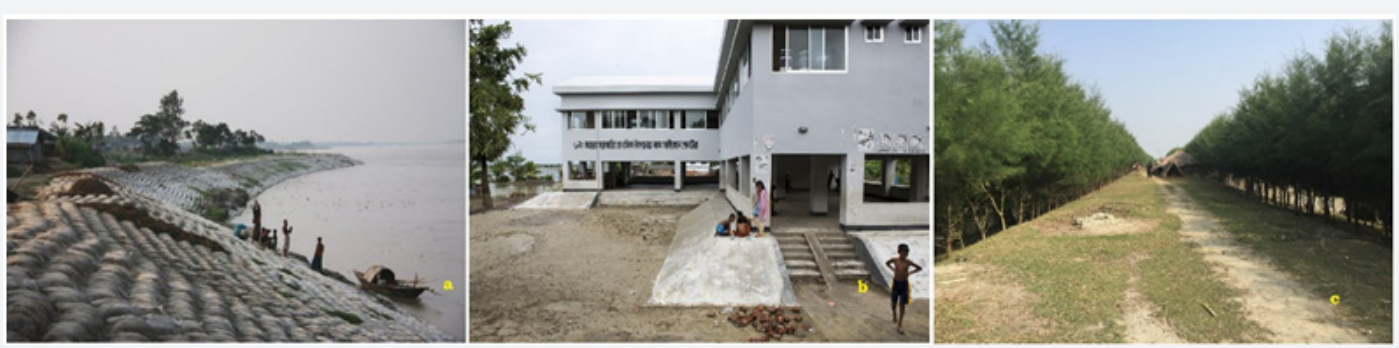

Figure 6: Different types of structural adaptation to sea level rise in the coastline of Bangladesh:

a) Newly built coastal flood protection embankment (source: www.manchester.ac.uk);

b) Multipurpose cyclone shelter centre;

c) Coastal mangrove afforestation (source: www.cdsp.org.bd).

Construction of multipurpose cyclone shelters: An important and widely acceptable disaster and flood management option in Bangladesh is the construction of multipurpose cyclone shelters. These shelters have the following facilities raised plinth height, installing toilets on raised ground, installing tubewells, food pres- ervation place, separate washroom for male and female, separate room for livestock, etc. Each shelter is designed to serve approximately 2,000 people and to function as schools for children and community clinic in some places (Figure 6). 
Bank protection works: In addition to soft measures, there are several hard measures including seawall and revetment to protect the coast from erosion. This kind of measures, however, is still few in the coastal areas as it takes a huge investment and long-term maintenance. Coastal afforestation: In recent years, plantations in the coastal area as well as along the embankments are being extensively conducted to enhance flood mitigation measures in the coastal zone by the Bangladesh Forest Department since 196061 . Up to 2010, approximately 190,000 ha of accreted lands have been brought under coastal mangrove plantations (Figure 6). Additionally, till 2013, a total of 1,92,395 ha mangrove, 8,690 ha non-mangrove, 2,873 ha goalpata (Nypa fruticans) and 12,127 km strip plantations have been raised in the coastal areas [85].

Increased surface water flow: The major initiatives to reduce salinity intrusion are the increasing surface water flows from upstream, and protection of agricultural lands by constructing dykes. 'The Gorai River Restoration Project' is an example of increasing surface water flows through deviating water from the Ganges River towards the southwest. The effectiveness of such measures is high, but feasibility is low because of the high cost. Possibilities for increased local storage of fresh surface and groundwater in the area itself are low as well.

\section{Integration of community participation into main- streaming adaptation}

Mainstreaming adaptation process is the systematic coordination and partnership across institutions, stakeholders and tiers, and integration of local to country level development plans to reduce the climate vulnerabilities and adapt to the change. The government of Bangladesh has taken the necessary steps to facilitate achieving mainstreaming across all sectors and at every level. Some of the basic prerequisites for mainstreaming are awareness, orientation, capacity building, and advocacy at different levels and spheres of operation.

Klein et al. [86] argued that mainstreaming adaptation through community participation is more sustainable, effective and efficient than designing and managing policies separately from ongoing activities. The government, multilateral and bilateral agencies, and non-government agencies were taking an interest in CBA and starting to implement larger scale CBA programmes at the grassroots level [87]. However, CBA is grounded in community values, implemented by local practitioners but insufficient attention was given to building up links with government and political structures [88].

Systematically mainstreaming local adaptation approaches into local, regional and national government structures, policies, laws and planning processes is usually the best way to support the wide-scale replication of local approaches and achieve impact at scale [89]. Bangladesh is stepping up to address climate change issues in national-level planning processes by mainstreaming climate change adaptation and mitigation as well as establishing climate financing mechanisms. Multi-sectoral involvement and coordination at the national level, cascading into local-level planning processes, could have the potential to bring tangible benefits for the nation (Figure 7). Nevertheless, synergies between plans and programmes need to be strengthened to achieve pro-poor, environment-friendly, and climate-resilient development [90].

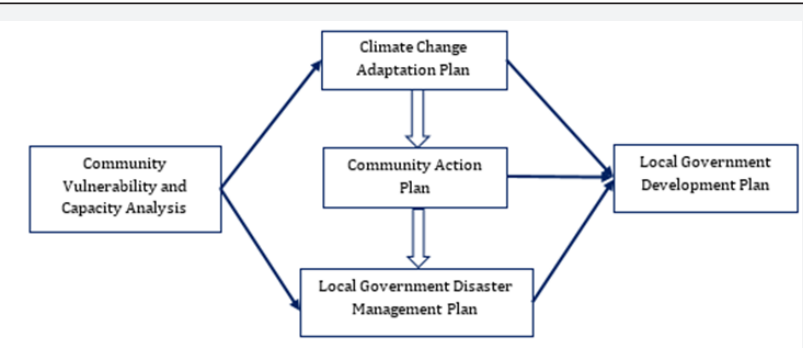

Figure 7: Integration of community-based adaptation into disaster risk reduction planning processes in Bangladesh (adapted from King [41]).

However, the study suggests that local institutions- public or private- can make a bridge between community participation and national level planning through facilitating adaptive support to the most vulnerable and excluded group of the society. Reid and Huq [87] stated that many CBA practitioners are based in NGOs, and increasingly government agencies, where it is difficult to dedicate much time to publishing work in academic journals. This means that much of their knowledge and experience is not shared as widely as it could be. For this reason, there is a need for extensive research on how to integrate community participation into national level frameworks. Finally, community participation in mainstreaming adaptation must build on improved learning from older natural resource management disciplines such as com- munity-based natural resource management, however, could help inform CBA practice and policy-making [90].

In response to climate change risk, community participation has also been criticized for the problem of 'effectiveness and 'effectiveness and legitimacy' or 'too generally identified' the vulnerability and limited scope for the local institution to implement adaptation. Involvement of local institutions in the development of adaptation strategies is crucial where humanitarian organizations could lead adaptation measures to protect communities against impending climate risks as decades of experience in working with local actors to support local stakeholders [91]. 
Involvement of local communities in CBA projects, indeed, does not require a lot of money rather CBA practices aware local communities to climate change risks, empower them to take an emergency decision, connect to social networks for information and resources, and enable to take part in the decision-making process [92]. The decentralization model of 'Integrated Planning for Sustainable Water Management' project created scope for the community to assert 'local authority' in water management. The project has initiated a long prevailing centralized and top-down model of water management towards a bottom-up and inclusive model of successful adaptation option [60].

In evaluating LACC project's success, Baas and Ramasamy [78] stress that for reducing vulnerability and ensuring resilience to climate change and effective community participation is crucial, and thereby it is imperative to integrate it in the institutions where 'top-down' approach and policy process were used. Likewise, evaluation of CBACC-CF project, it was identified that there is a lack of proper implementation and participation of local communities; even suggest that the project is not the most prioritized need for them to reduce vulnerability. As for example, in Noakhali district, the greatest vulnerability is 'water logging and salinity intrusion' but government facilitated polder development projects that reduce regular water flow [57].

\section{Coastal zone management from sea level rise in Ban- gladesh}

After the independence, with the support of development partners, Bangladesh invested over US $\$ 10$ billion in making the vulnerable people resilient to climate change. The prioritized areas for investments in coastal zone include cyclone shelters, coastal embankment projects, coastal greenbelt project, Sundarbans Biodiversity Conservation Project, different disaster management projects, and building embankments, develop polders and cyclone shelters [93]. Bangladesh formulated a National Coastal Zone Policy (CZP) in 2005 to ensure sustainable development of coastal communities and to cope with the future climate change events. The intention of this policy was to harmonize coastal zone policies across sectors, ministries, departments and agencies to coordinate their activities. CZP proposes an institutional framework for monitoring SLR and formulating programs to augment adaptation to SLR related impacts. CZP suggested for protecting the coastline, soil erosion, floods and storm surge at the coastlines by sea facing embankment which is later adopted in the NAPA (National Adaptation Programme of Action) of Bangladesh [94]. Moreover, a project has been executed by the Water Resources Planning Organization (WARPO) to develop an 'Integrated Coastal Zone Management Plan' from 2002-2006. It was aimed at developing capabilities and priority actions for coastal development in Bangladesh [95].

Promoting adaptation to coastal crop agriculture to combat increased salinity, and coastal fisheries through a culture of salt tolerant fish species; reduction of climate change hazards through coastal afforestation with community participation; providing drinking water to coastal communities for reducing increased salinity impact caused by SLR; promoting research on saline tolerant crop varieties to facilitate further adaptation in the future; and enhancing the resilience of urban infrastructure and industries adversely impacted by climate change including floods and cyclone, etc. are prioritizes actions and adaptation needs identified by NAPA [96].

Similarly, development of climate-resilient cropping system and production technologies; local and indigenous adaptation against salinity; improvement of disaster warning system; repair and maintenance of cyclone shelters; repair and maintenance of existing infrastructures like coastal polders, dams, roads, culverts and bridges; preparatory studies for adaptation against SLR and its impact; and coastal afforestation and reforestation programme, etc. were prioritized activities identified by Bangladesh Climate Change Strategy and Action Plan (BCCSAP) [93].

Strategies for adaptation need to focus on the needs of the community and aim to reduce the impact of SLR in the local ecosystem. Valuing the local knowledge that is already using to cope with the SLR alongside science-based knowledge is key to developing sound adaptation strategies. New salt and flood tolerant agriculture technologies should be promoted at household and community level. Diversification of crop agriculture, the establishment of seed banks, increased alternative livelihood options such as homestead gardening, horticulture, floating gardens, and handicraft production, mass awareness raising, and information sharing, etc. are priority areas of community adaptation under coastal zone management.

IPCC defined three generic approaches to adapt to SLR and coastal zone management are:

a) planned retreat,

b) accommodation, and

c) protection (Figure 8).

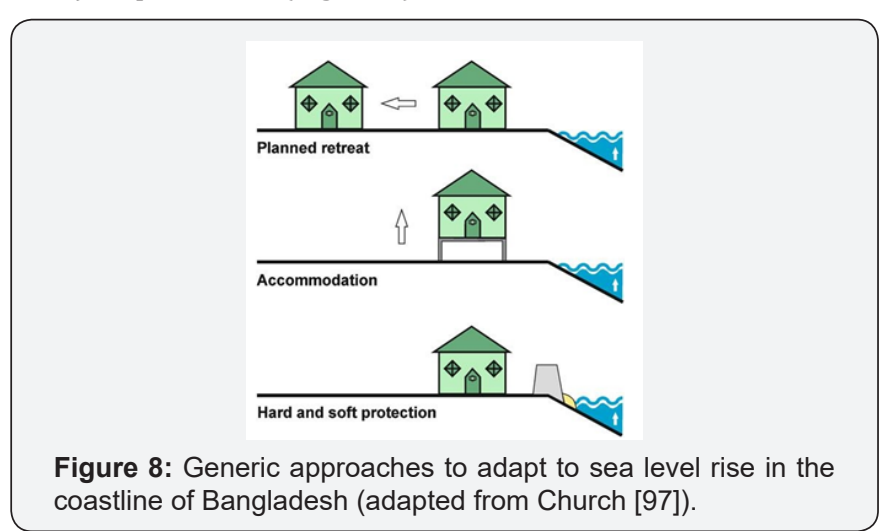

Planned retreat involves pulling back from the cost using land use planning and development control. Accommodation involves adjusting the human use of the coastal zone using flood resilience, warning systems, and insurance. Protection involves engineering 
solutions reducing human impacts in the coastal zone otherwise impacted without protection. The most popular adaptation method used is the protection method because of its lower cost and feasibility [6].

Similarly, considering the SLR situation in Bangladesh, the Asian Disaster Preparedness Center recommended some housing structures for the flood-prone, water logging and saline prone coastal areas like:

a) Stabilization of the typical earthen plinth can be carried out with a mixture of earth and cement;

b) Brick perimeter wall around the typical earthen plinth;

c) Brick-cement concrete flooring;

d) Coating lower end of the bamboo/timber posts for protecting from dampness;

e) Protection of bamboo/timber posts by supporting on concrete stumps embedded into the plinth or ground and connecting them by mild steel clamps;

f) Reinforced concrete post, etc. $[97,98]$.

\section{Conclusion}

Community participation in adaptation is recognized as a valid approach worldwide to reduce climate change vulnerabilities particularly SLR vulnerabilities and enhancing community resilience capacity. Climate change impacts are experienced mainly at local level thus IK and adaptive practices are important for proper resilience, and thereby most resilience programmes should be managed and implemented locally. The study identifies that there is a gap in government policies and strategies as very limited scope exist there for local communities to get involved in staterun programs. Both NAPA and BCCSAP paid little attention to CBA priorities. In addition, where community participation integrates into programme formulation and implementation, their community participation has not achieved its intended benefits due to improper identification of climate change 'risk' or for inappropriate 'top-down' decision-making approach. Institutionalization of local adaptation strategy into national level framework will, in turn, serve as an important impetus for implementing climate change adaptation programs. The following Table 2 shows the weaknesses of government strategies and given some suggestions for effective CBA to SLR in the Coastaline of Bangladesh.

Table 2: Summary of the governmental strategy to sea level rise mitigation and suggestions for the future.

\begin{tabular}{|c|c|c|}
\hline Strategy & Weakness & Suggestion \\
\hline $\begin{array}{l}\text {-NAPA } 2005 \\
\text {-Coastal Zone } \\
\text { Management } \\
\text { Policy } 2005 \\
\text {-BCCSAP } 2009\end{array}$ & $\begin{array}{l}\text {-Top-down approach; } \\
\text {-Pre-defined adaptation option; } \\
\text {-Limited scope of community } \\
\text { participation in planning and } \\
\text { implementation; } \\
\text {-Limited scope to decision- } \\
\text { making by local communities }\end{array}$ & $\begin{array}{l}\text {-Ensure all the needs/ priorities come from community through bottom-up approach; } \\
\text {-Integrate CBA into governmental policies; Incorporate community participation to all } \\
\text { adaptation programmes; } \\
\text {-Long-term non-cash benefits need to be complemented by more visible direct household } \\
\text { benefits; } \\
\text {-Involve local communities in the decision-making process; } \\
\text {-Prioritize IK into adaptation; } \\
\text {-Involve local communities through legal activism in project planning, design and } \\
\text { implementation; } \\
\text {-Boost government-NGO participation for effective CBA approach; } \\
\text {-Need extensive research on community participation and ways to integrate it into } \\
\text { mainstreaming adaptation; } \\
\text {-Successful CBA project need to be scale-up; } \\
\text {-Ensure multi-sectoral engagement and collaboration between different sectors and } \\
\text { ministries; }\end{array}$ \\
\hline
\end{tabular}

Community-based approaches are driven by local institutions (NGO, CSO and CBO) who work with their limited capacities and resources to boost the process of CBA to SLR alongside the government. However, their efforts are not properly recognized and reflected in national programmes and climate change policies. In addition, limitation of government bodies as lack of intra-government and inter-government institutional coordination hinders the effectiveness of CBA projects. Institutionalization of local communities' involvement into national level framework will, in turn, serve as an important impetus for implementing SLR adaptive programmes. SLR resilience strategy of Bangladesh should consider IK and learning from local communities and integrate that into wider national policies. Local communities should be involved in project implementation through legal activism. Finally, to ensure pro-poor climate governance and effective resilience and adaptation to SLR, the government should respect local communities and local institutions who work for them, heed their adaptation priorities, and change the top-down approaches to bottom-up approaches.

\section{Acknowledgement}

M. A. Haque and D. Rahman awarded a research grant from the Bangladesh Institute of Social Research (BISR) Trust under its 'Adjunct Researcher Fellowship' programme to conduct the study.

\section{References}

1. IPCC [Intergovernmental Panel on Climate Change] (2013) Climate Change 2013: The Physical Science Basis, Contribution of Working Group I to the Fifth Assessment Report of the Intergovernmental Panel on Climate Change. Cambridge University Press, New York. 
2. IPCC [Intergovernmental Panel on Climate Change] (2007) Climate Change 2007: Impacts, Adaptation and Vulnerability, Contribution of Working Group II to the Fourth Assessment Report of Intergovernmental Panel on Climate Change. Cambridge University Press, New York.

3. National Research Council of the National Academies (2012) SeaLevel Rise for the Coasts of California, Oregon, and Washington: Past, Present, and Future. The National Academies Press, Washington D.C, USA.

4. USGCRP (U.S. Global Change Research Program)-Inter-agency Collaboration (2014) Climate Change Impacts in the United States: The Third National Climate Assessment, Washington D.C, USA.

5. World Bank (2013) $4^{0}$ Turn Down the Heat: Climate Extremes, Regional Impacts, and the Case for Resilience, The World Bank, New York.

6. Dronkers J, Gilbert JTE, Butler LW, Carey JJ, Campbell J, et al. (1990) Coastal Zone Management: In: Climate change: The IPCC Response Strategies, Geneva: Intergovernmental Panel on Climate Change. 133159.

7. Nicholls RJ, Tol RSJ (2006) Impacts and responses to sea-level rise: A global analysis of the SRES scenarios over the twenty-first century. Philos Trans A Math Phys Eng Sci 364(1841): 1073-1095.

8. Paul BK (2009) Why relatively fewer people died? The case of Bangladesh's cyclone Sidr. Nat Hazar 50(2): 289-304.

9. Alam K, Rahman MH (2014) Women in natural disasters: A case study from southern coastal region of Bangladesh. Int J Disast Risk Reduc 8: 68-82.

10. Minar MH, Hossain MB, Shamsuddin MD (2013) Climate change and coastal zone of Bangladesh: Vulnerability, resilience and adaptability. Middle-East J Scient Res 13(1): 114-120.

11. Shamim C (2008) Alternative views of environmental security in a less developed country: The case of Bangladesh. Journal of Third World Studies 25(1): 253-272.

12. Hossain M (2008) Sea level rise, natural disasters and threats to human security in Bangladesh, South Asia: Environment and Human Securities Conference, Canberra.

13. Alam M, Murray LA (2005) Facing Up to Climate Change in South Asia, Gatekeeper Series-118, International Institute for Environment and Development (IIED), London.

14. Islam N, Ahmed MF, Tanveer SA, Badruzzaman ABM (2002) The broader significance of the environment movement in Bangladesh, $2^{\text {nd }}$ International Conference on Bangladesh Environment (ICBEN-2002), Bangladesh Poribesh Andolon (BAPA) Dhaka, pp. 1-16.

15. Ahsan DA, DelValls TA, Blasco J (2009) The relationship of national and international environmental NGOs in Bangladesh and their role in wetland conservation. Int J Environ Res 3(1): 23-34.

16. Alam M, Rabbani GM (2007) Vulnerabilities and responses to climate change for Dhaka. Int Inst Environ Develop 19(1): 81-97.

17. Haque MA, Rahman D, Rahman MH (2016) The importance of community based approach to reduce sea level rise vulnerability and enhance resilience capacity in the coastal areas of Bangladesh: A review. J Sust Sci Manage 11(2): 81-100.

18. BBS [Bangladesh Bureau of Statistics] (2011) Population and Housing Census 2011: Socio-Economic of Demographic People, Ministry of Planning, Dhaka.

19. Sarker MH, Ahmed F (2015) Climate Change Vulnerability of Drinking Water Supply Infrastructure in Coastal Areas of Bangladesh, IUCN Bangladesh Country Office, Dhaka.

20. Climate Change Cell (2016) Assessment of Sea Level Rise on Bangladesh Coast through Trend Analysis, Department of Environment, Dhaka.
21. CEGIS [Center for Environmental and Geographic Information Services] and Department of Environment (2011) Final Report on Programmes Containing Measures to Facilitate Adaptation to Climate Change of the Second National Communication Project of Bangladesh, Dhaka.

22. Haque SA (2006) Salinity problems and crop production in coastal regions of Bangladesh. Pak J Bot 38(5): 1359-1365.

23. Hoque MA, Saika U, Sarder BC, Biswas KK (2013) Environmental and socio-economic impacts of salinity intrusion in the coastal area: A case study on Munshigong Union, Shymnagor, Satkhira. Jahangir Uni Environ Bullet 2: 41-49.

24. Ericson JP, Vörösmarty CJ, Dingman SL, Ward LG, Meybeck M (2006) Effective sea-level rise and deltas: Causes of change and human dimension implications. Glob Planet Chang 50(1-2): 63-82.

25.SMRC [SAARC Meteorological Research Center] (2003) The Vulnerability Assessment of the SAARC Coastal Region Due to Sea Level Rise: Bangladesh Case Study, Dhaka.

26. Khan AE, Xun WW, Ahsan H, Vineis P (2011) Climate change, sealevel rise, \& health impacts in Bangladesh. Environ Sci Policy Sustain Develop 53(5): 18-33.

27. UK Department for Environment, Food and Rural Affairs (2007) Investigating the Impact of Relative Sea-level Rise on Coastal Communities and their Livelihoods in Bangladesh, Institute of Water Modelling and Center for Environmental and Geographic Information Services, Dhaka.

28. Brecht H, Dasgupta S, Laplante B, Murray S, Wheeler D (2012) Sea-level rise and storm surges: High stakes for a small number of developing countries. The Journal of Environment \& Development 21(1): 120-138.

29. Hanson S, Nicholls R, Ranger N, Hallegatte S, Corfee-Morlot J, et al. (2011) A global ranking of port cities with high exposure to climate extremes. Climate Chang 104(1): 89-111.

30. Yu W, Alam M, Hassan A, Khan AS, Ruane A, et al. (2010) Climate Change Risks and Food Security in Bangladesh, Routledge, London, UK.

31. UNESCO [United Nations Educational, Scientific and Cultural Organization] (2007) Case Studies on Climate Change and World Heritage, UNESCO World Heritage Centre, Paris.

32. Mazda Y, Magi M, Kogo M, Hong PN (1997) Mangroves as a coastal protection from waves in the Tong King delta, Vietnam. Mangr Salt Mars 1(2): 127-135.

33. Kathiresan K, Rajendran N (2005) Coastal mangrove forests mitigated tsunami. Estuar Coast Shelf Sci 65: 601-606.

34.Vermaat JE, Thampanya U (2006) Mangroves mitigate tsunami damage: A further response. Estuar Coast Shelf Sci 69: 1-3.

35. Loucks C, Barber-Meyer S, Hossain MAA, Barlow A, Chowdhury RM (2010) Sea level rise and tigers: Predicted impacts to Bangladesh's Sundarbans mangroves. Climate Change 98: 291.

36. Smith BD, Braulik F, Strindberg S, Mansur R, Diyan MAA, et al. (2009) Habitat selection of freshwater-dependent cetaceans and the potential effects of declining freshwater flows and sea-level rise in waterways of the Sundarbans mangrove forest, Bangladesh. Aqua Conserv: Mar Freshw Ecosyst 19(2): 209-225.

37.CEGIS [Center for Environmental and Geographic Information Services] (2006) Impacts of Sea Level Rise on Landuse Suitability and Adaptation Options, Dhaka.

38. Miyaguchi T (2011) Community-based adaptation to climate change: The concept, challenges and way forward. SANSAI: An Environ J Glob Commu 5: 21-35.

39. Reid H, Alam M, Berger R, Cannon T, Huq S, et al. (2009) Communitybased Adaptation to Climate Change: An Overview. In: Reid H, Cannon T, Berger R, Alam M, Milliga A (Eds), Participatory Learning and 
Action (PLA)-60-Community-Based Adaptation to Climate Change, International Institute for Environment and Development (IIED), London , pp.11-33.

40. Dodman D, Mitlin D (2013) Challenges for community-based adaptation: Discovering the potential for transformation. J Int Develop 25(5): 640-659.

41. King S (2014) Community-Based Adaptation in Practice: A global overview of CARE International's practice of Community-Based Adaptation (CBA) to climate change, CARE International, London.

42. Reid H, Alam M, Berger R, Cannon T, Huq S, et al. (2009) Communitybased Adaptation to Climate Change: An Overview, Participatory Learning and Action-60, International Institute for Environment and Development (IIED), London, UK.

43. Ayers J, Forsyth T (2009) Community-based adaptation to climate change. Environ 51(4): 22-31.

44. Forsyth T (2013) Community-based adaptation: A review of past and future challenges. WIREs Clim Chang 4(5): 439-446.

45. World Development Indicators. Accessed on 23 October 2018.

46. Joy KZK (2010) Hanging vegetable gardens. Tiempo 75: 8-11.

47. Reid H, Schipper ELF (2014) In Community-Based Adaptation to Climate Change: Scaling it Up. In: Schipper ELF, Ayers J, Reid H, Huq S, Rahman A (Eds.), Routledge, pp. 3-21.

48. Fukuoka F, Nyandiga C, Mitchell P, Chandani A, Hardcastle J, et al. (2014) In Community-Based Adaptation to Climate Change: Scaling it Up. In: Schipper ELF, Ayers J, Reid H, Huq S, Rahman A (Eds.), Routledge, pp. 75-87.

49. Khan AE, Ireson A, Kovats S, Mojumder SK, Khusru A, et al. (2011) Drinking water salinity and maternal health in coastal Bangladesh: Implications of climate change Environ Health Perspect 119(9): 13281332.

50. Shumake-Guillemot J, Ebi KL, Kabir I, Nguyen T, Malkawi M (2014) Scaling up community-based adaptation to protect health from climate change. In: Schipper ELF, Ayers J, Reid H, Huq S, Rahman A (Eds.), Community-Based Adaptation to Climate Change: Scaling it Up, Routledge, pp. 155-171.

51. WHO [World Health Organization]-SEARO [South-East Asia Regional Office] (2008) How is Climate Change Affecting Our Health: A Manual for Teachers, New Delhi?

52. Irfanullah HM, Azad MAK, Kamruzzaman M, Waheb MA (2011) Floating gardens in Bangladesh: A means to rebuild lives after devastating flood. Int J Trad Know 10(1): 31-38.

53. Practical Action (2005) Floating Gardens in Bangladesh, Dhaka.

54. Rahman A (2011) Floating Vegetable Bed Cultivation, In: Misdorp R (Ed), Climate of Coastal Cooperation, Leiden, the Netherlands. 179180 .

55. IUCN [International Union for Conservation of Nature] (2005) Promotion of Adaptation to Climate Change and Climate Variability in Bangladesh, Dhaka.

56. CARE Bangladesh (2005) The Reducing Vulnerability to Climate Change (RVCC) Project: Reflecting on Lessons Learned, Dhaka.

57. Ayers J (2011) Resolving the adaptation paradox: Exploring the potential for deliberative adaptation policy-making in Bangladesh. Glob Environ Polit 11(1): 62-88.

58. Masum SJH (2010) Living with Climate Change: Understanding Human Insecurity for Surviving in Climate Change Vulnerable Bangladesh, Costal Development Partnership, Dhaka.
59. Rawlani AK, Sovacool BK (2011) Building responsiveness to climate change through community based adaptation in Bangladesh. Mitig Adapt Strat Global Change 16(8): 845-863.

60. IPSWAM [Integrated Planning for Sustainable Water Management] (2011) Evaluation Report, Embassy of the Kingdom of the Netherlands and Bangladesh Water Development Board, Dhaka.

61. Nakagawa Y, Shaw R (2004) Social capital: A missing link to disaster recovery. Int J Mass Emerge Disast 22(1): 5-34.

62. Heijmans A, Lorna V (2001) Citizenry-Based and DevelopmentOriented Disaster Response: Experiences and Practices in Disaster Management of the Citizens, Disaster Response Network in the Philippines, Centre for Disaster Preparedness.

63. Islam R, Walkerden G (2015) How do links between households and NGOs promote disaster resilience and recovery? A case study of linking social networks on the Bangladeshi Coast. Nat Hazar 78(3): 17071727.

64.Wind TR, Komproe IH (2012) The mechanisms that associate community social capital with post-disaster mental health: A multilevel model. Soc Sci Medi 75(9): 1715-1720.

65. Adeola FO, Picou JS (2014) Social capital and the mental health impacts of hurricane Katrina: Assessing long-term patterns of psychosocial distress. Int J Mass Emerg Disast 32(1): 121-156.

66. Green GP, Haines A (2011) Asset Building and Community Development, Thousand Oaks, CA, Sage.

67. Ahmed AU (2001) Adaptability of Bangladesh's crop agriculture to climate change: Possibilities and limitations. Asia Pac J Environ Develop 7(1): 71-93.

68. Islam T, Atkins PJ (2007) Indigenous floating cultivation: A sustainable agricultural practice in the wetlands of Bangladesh. Develop Prac 17: 130-136.

69. Mahmood SMS, Najneen F, Hoque KS, Rahman S, Shamim MM (2010) Climate change: A study on impact and people's perception (a case study on Mongla Upazila, Bagerhat District, Bangladesh). Bangladesh Res Pub J 4(2): 153-164.

70. Alam K (2011) Adaptation of coastal dwellers: The case of Bangladesh. Man Develop 33(3): 91-112.

71. Anik SI, Khan MASA (2012) Climate change adaptation through local knowledge in the north eastern region of Bangladesh. Mitig Adapt Strat Glob Chang 17(8): 879-896.

72. Rahman MH,Alam K (2016) Forest dependent indigenous communities' perception and adaptation to climate change through local knowledge in the protected area -A Bangladesh case study. Clim 4(1): 12.

73. IUCN [International Union for Conservation of Nature], UNEP [United Nations Environment Programem], UNU [United Nations University] (2009) Biodiversity Conservation and Response to Climate Variability at Community Level, IUCN Bangladesh Country Office, Dhaka.

74. IUCN [International Union for Conservation of Nature] (2005) Baira: The Floating Gardens for Sustainable Livelihood, Dhaka.

75.CARE-Bangladesh and BDPC [Bangladesh Disaster Preparedness Centre] (2009) Documentation and Promotion of Transferable Indigenous Knowledge and Coping Strategies for Disaster Risk Reduction, Dhaka.

76. Sen S, Emran DMA, Reza MA, Lamin S (2007) Climate Change: Indigenous Knowledge and Adaptation (in Bangali), BARCIK, Dhaka.

77. Irfanullah HM, Motaleb MA (2011) Reading nature's mind: Disaster management by indigenous peoples of Bangladesh. Indian J Tradit Know 10(1): 80-90. 
78. Baas S, Ramasamy S (2008) Community Based Adaptation in Action: A case study from Bangladesh. Project Summary Report (Phase 1): Improved Adaptive Capacity to Climate Change for Sustainable Livelihoods in the Agriculture Sector, FAO Environment and Natural Resources Service Series-14, Rome.

79. Shampa MIMP (2012) Tidal river management (TRM) for selected coastal area of Bangladesh to mitigate drainage congestion. International Journal of Scientific \& Technology Research 1(5): 1-6.

80. Hossain F, Khan ZH, Shum CK (2015) Tidal river management in Bangladesh. Nature Clim Chang 5: 492.

81. Ahmed N, Garnett ST (2011) Integrated rice-fish farming in Bangladesh: Meeting the challenges of food security. Food Secur 3(1): 81-92.

82. Ahmed AU (2004) Adaptation to climate change in Bangladesh: Learning by doing, UNFCCC Workshop on Adaptation, Bonn, Germany.

83. BRRI [Bangladesh Rice Research Institute]-FAO [Food and Agriculture Organizations of the United Nations] (2009) Results and Findings from BRRI-FAO Collaboration under Project Improved Adaptive Capacity to Climate Change for Sustainable Livelihoods in the Agricultural Sector in Bangladesh, Dhaka.

84. FAO [Food and Agriculture Organization of the United Nations] (2008) Community-Based Adaptation into Action: A Case Study from Bangladesh, Rome.

85. Islam SA, Rahman MM (2015) Coastal afforestation in Bangladesh to combat climate change induced hazards. J Sci Technol Environ Inform 2(1): 13-25.

86. Klein RJT, Schipper L, Dessai S (2005) Integrating mitigation and adaptation into climate and development policy: Three research questions. Environ Sci Poli 8(6): 579-588.

87. Reid H, Huq S (2014) Mainstreaming community-based adaptation intonational and local planning. Clim Develop 6(4): 291-292.
88. Alam K, Rahman MH (2017) The Role of Women in Disaster Resilience, In: Madu CN, Kuei C (Eds.), Handbook of Disaster Risk Reduction and Management. World Scientific Press, New Jersey, USA, pp. 697-719.

89. Reid H (2016) Ecosystem-and community-based adaptation: Learning from community-based natural resource management. Clim Develop 8(1): 4-9.

90. Pervin M (2013) Mainstreaming Climate Change Resilience into Development Planning in Bangladesh, International Institute for Environment and Development (IIED), London, UK.

91. IFRC [International Federation of Red Cross and Red Crescent Societies] (2009) Climate Change Adaptation Strategies for Local Impact: Key Messages for UNFCCC Negotiators, Geneva.

92. Dumaru P (2010) Community-based adaptation: Enhancing community adaptive capacity in Druadrua Island, Fiji. WIREs Clim Chang 1(5): 751-763.

93. MoEF [Ministry of Environment and Forests] (2009) Bangladesh Climate Change Strategy and Action Plan (BCCSAP), Dhaka.

94. MoWR [Ministry of Water Resources] (2005) Coastal Zone Policy 2005, Dhaka.

95. WARPO [Water Resources Planning Organization] (2005) Project Completion Report of Integrated Coastal Zone Management Plan (ICZMP), Dhaka.

96. MoEF [Ministry of Environment and Forests] (2009) National Adaptation Program of Action (NAPA), Dhaka.

97. Church JA, Woodworth PL, Aarup T, Wilson WS (Eds) (2010) Understanding Sea-Level Rise and Variability, Wiley-Blackwell, New Jersey, USA.

98. Ahmed KI (2005) Handbook on Design and Construction of Housing for Flood-prone Rural Areas of Bangladesh. Asian Disaster Preparedness Center, Bangkok.

\section{Your next submission with Juniper Publishers} will reach you the below assets

- Quality Editorial service

- Swift Peer Review

- Reprints availability

- E-prints Service

- Manuscript Podcast for convenient understanding

- Global attainment for your research

- Manuscript accessibility in different formats

( Pdf, E-pub, Full Text, Audio)

- Unceasing customer service

Track the below URL for one-step submission https://juniperpublishers.com/online-submission.php 